\title{
Intercultural Mobility and European Identity: Impact of the Erasmus Exchange Programme in Terms of Cultural Differences
}

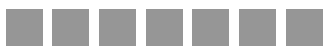

Fatih Goksu

ORCID: 0000-0001-7107-3408

ERASMUS UNIVERSITY ROTTERDAM, THE NETHERLANDS

https://doi.org/10.19195/1899-5101.13.1(25).6

\begin{abstract}
European mobility programmes have been seen as a promising method to promote European identity, particularly with a focus on young generations. In this article, I discussed the constructing role of the Erasmus exchange programme by employing the result of direct crosscultural interaction. Data from Eurobarometer surveys and outcomes concluded from the semistructured interviews revealed that socialising with other Europeans strengthened European identity but contact with the host country remained limited. Different from other studies, this paper also reveals that the national identity of the participants precisely empower as a result of coaction. Furthermore, for the first time in the literature, semi-structured interviews unveiled that cultural differences such as stereotypes and prejudices have no negative effect in promoting European identity among students. Rather, it generates a positive impact for the awareness of national identity.
\end{abstract}

KEYWORDS: Erasmus Programme, European identity, national identity, cultural differences, semistructured interviews.

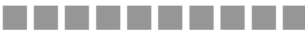

\section{INTRODUCTION}

The idea that contact between people from different nationalities can have a transformative effect on attitudes was popular even back in the 1950s. According to international integration theory developed by Deutsch (1953) and intergroup contact theory presented by Allport (1954), social interaction between different groups contributes to a sense of community that eventually leads to an integrated society. The main argument of these theories is that under convenient conditions, prejudices between people or groups might disappear through personal interaction. Another theory, 'the common in-group identity model' progresses further and claims that "the interaction between groups does not only reduce intergroup bias but also 
causes group members to re-categorise themselves as a single group rather than categorising themselves as two separate groups" (Gaertner et al., 1993, p. 3). Inspired by these approaches, Fligstein (2008) argues that increased interactions between Europeans can lead to a common European identity. According to Fligstein, due to their interpersonal contact, "people see each other less as Italian or French, and thus, foreign and more and more as sharing common interests, a process that eventually will lead to seeing themselves more as Europeans and less as having merely a national identity" (Fligstein, 2008, p. 139). These whole arguments highlight the significance of transnational-social contact as an instrument for identity-formation and its importance on reducing intergroup bias.

Today, the potential of cross-border mobility provides an opportunity for the European Union (EU). As Sigala mentions "border controls between most EU countries have disappeared, and travelling to and living in other European countries has become easier, Europeans have more chances than ever to interact with each other and, in theory, to develop a common identity" (2010, p. 242). Indeed, mobility is now in Europe considered as a favored concept that changes the ways of being, and pushes people to think beyond societies. However, the literature lacks reliable studies measuring the relationship between international mobility and European identity. Outcomes, such as cross-border mobility, promotes European identity as assumed rather than established. Therefore, the main purpose of this study is to create another effort to reveal the connection between the impact of cross-cultural communications and the identification process.

Boneu (2003) discusses that only education and youth-driven movements will help to achieve an attitude that will evolve in togetherness. Accordingly, in the last couple of decades, Europe's education programmes provisioned for a stream of students with diverse religious, social, and ethnic backgrounds. This results in an exchange of ideas and permits people to obtain a valuable cultural experience with a programme named Erasmus. Every year, thousands of students leave home for the purpose of participating in an educational experience in a country other than their home. Studying abroad, as a consequence, impacts on students in the areas of language use, academic accomplishment, intercultural and personal development, but the real purpose of the programme is to promote European wefeeling (Dwyer, 2004). As former European Commissioner for Education Jan Figel (2006, p. 3) declared in one of his speeches, it is clear that Erasmus contributes enormously to forge and promote a European identity.

In this context, it is expected that socialising with other European students throughout an exchange programme has the potential to promote a sense of European identity among the participants. In this article, the paper investigates this phenomenon namely, whether social contacts with locals and other international students during the exchange programme promotes European identity but the paper contributes to the existing literature by adding different concepts. For instance, Van Mol's (2013) comparative study suggests even if students become more 
European throughout the exchange, this relationship is highly dependent on the specific contexts which students originate from. Within this framework this paper, different from all other works, examines the role of national identity in determining European identification. Furthermore, the concept of European identity is also characterised by cultural differences as Fernandez's (2005) qualitative study reveals; acceptance of mutual cultural differences plays a key role in the definition of belonging to Europe. In this sense, the paper newly introduces the question if cultural differences have a negative effect on the development of European identity during the sojourn.

\section{EUROPEAN IDENTITY AND EU POLICIES}

Scholars claim that Europe will function as a proper democratic system of governance, which will recognize the legitimate majority decisions if political communities consist of people who share the same political identity (Bruter, 2005; Herrmann \& Brewer, 2004). According to Habermas (2001), EU constitutions can enable European citizens to develop a common political identity on the grounds that the connection of three elements, such as the emergence of a European civil society, construction of a European-wide public sphere and a shared political culture eventually will supply the EU with the necessary conditions for identity formation. However, Meyer (2006) argues that the EU is still far from the achievement of a political identity that would be sufficiently placed in the hearts and minds of its citizens, since political identity should not only be based on consciousness but also be based on belonging that will go beyond national identities.

Indeed, scholars argue that the nation-state phenomenon is not a proper model for the EU (Decker, 2002). Since the EU includes many nation-states, the compatibility of national identities and European identity has been the subject of controversy in the context of the European integration project (Kostakopoulou, 2001, p. 17). Deep-rooted national identities of the member states are presumed to have a weakening effect on the construction of supranational identity in Europe. In fact, the development of a sense of 'Europeanness' is hindered by the national policies of the member states towards the preservation and maintenance of the national identities. Nonetheless, Risse (2014) insists that European polity does not need to have demos, which replaces national identity with a European one; instead, one in which national and European identities may both co-exist and complement each other. Correspondingly some scholars (Kohn, 1955; Renan, 1996) do not identify national identity as something of a resistance to European integration, on the contrary, supranational integration could lead to supranational identity as Fligstein (2008, p. 140) agrees, "increased cross-border mobility promotes a "European national identity". Within this framework, the paper pursues this approach to investigate the role of national identity on the construction of European identity from the perspective of Erasmus students. 
Furthermore, national identity is considered as a part of the individual's social identity. Tajfel (1981, p. 255) describes social identity as "that part of an individual's self-concept which derives from his knowledge of membership of a social group or groups together with the value and emotional significance attached to that membership". This definition indicates two important aspects of social identity: emotional attachment and self-placement. Emotional attachment of the identity refers to the group that the individual belongs to, and the individual develops the feelings of mutual obligation among group members and establishes loyalty to the group (Tajfel, 1981). In the case of European identity, the emotional dimension falls into the emotional closeness that citizens have for Europe as a territorial entity, which implies a positive assessment of membership. The second aspect of social identity refers to self-placement, which is integrated with the multiplicity of identities (Turner et al., 1987). Namely, individuals can identify themselves with various social groups at various levels, for instance, with a socio-economic group in a local setting, with a political party at the national level, with a national attribute in an international context (Kohli, 2000). Scholars (Hermann \& Brewer, 2004; Tajfel, 1981) approach this diversity in terms of multiple identities and argue that people can possess multiple, non-conflicting identities and these identities might unite to form one individual identity. In this context, the focus of most of the research on European identity on the existence of identities includes identification as European.

Even though the theory of social identity presents a valuable instrument to conceptualize a component of European identity, difficulties remain, as having a European identity does not necessarily mean having higher-level attachment to the EU as a political community. European identity, which refers to a 'collective identity that underpins the EU can be challenged on the fact that the geographical and cultural notion of Europe is broader than the political community of the Union (Ceka \& Sojka, 2016, p. 5). However, Bruter (2005) claims that the concept of a political identity offers more, as he makes a separation between a civic and a cultural component; meaning that civic aspect refers to one's identification with the political structure, institutions, rights, etc. and cultural aspects refer to belonging based on one shared culture, values, religion, etc. Namely, apart from self-identity and positive image towards other Europeans, a political identity should connect citizens to the EU (Sigalas, 2010).

Nevertheless, it is debatable if positive images of Europe or attachment of its citizens to EU automatically lead to European identification. Even if social identity theory still maintains that individuals seek to attain a positive social identity, it is not certain that they will immediately identify with the group they perceive in positive terms, or attempt to emulate its behavior (Mihelj \& Petkova, 2012). Hence, the EU clearly recognized the importance of supporting economic and political unification with cultural facets. Smith (1995) explains that one of the main issues regarding the emergence of European identity is the reason that Europe lacks a unique culture that can connect the people of Europe together. Consequently, it 
is one of the assumptions that if the structure of European culture is promoted and protected sufficiently, European consciousness will naturally emerge.

Creating a European cultural identity is considered of vital importance in the political project of the European Union particularly with an emphasis on the younger generation. European cultural policies were developed and implemented by the $\mathrm{EU}$ institutions in the area of education in order to promote a sense of European identity among youngsters. Therefore, education initiatives such as European student exchange programmes formed as an idea and eventually led to a European Community strategy with the aim of a 'People's Europe' (Sigalas, 2010, p. 243). However, Hofstede (1991) argues that cultural differences among European countries are very considerable and as large as could be found anywhere in the world. Furthermore, Hogg (2006) argues that social identities also focus on negative characteristics such as stereotyping, ethnocentrism, discrimination, prejudice, and intergroup conflict. Therefore, many of these traits may prevent citizens developing a united social identity. Additionally, studies revealed that people who have strong cultural identities are more dominant or more prejudicial when interacting with others (Smith \& Hopkins, 2004). As mentioned earlier, each person has multiple dimensions of identities, usually depending on the nature of the social interaction. These interactions are the games of identity which are played everywhere in society (Hall, 1996) and this is exactly why we have to include the socialising feature of identity within intercultural communication. Because as Jensen (1998) notes, discussion on identity as a subject in intercultural communication depends on the topic, and what the participants are talking about. Some conversations will actualise national identity while other conversations will not concern national ideas at all. After all, the conversation still has to be seen in an intercultural context. In this regard, discussing cultural differences between students from the intercultural communication perspective will be another item to investigate for this study.

\section{EFFECTIVENESS OF THE ERASMUS PROGRAMME}

Several studies, including this one, have focused on the impact of student exchanges on the development of a sense of European identity. While some of the studies revealed that exchange students become more European throughout their exchange, particularly as a result of social interaction (King \& Ruiz-Gelices, 2003; Mitchell, 2012; Oborune, 2013; Stoeckel, 2016; Van Mol, 2018), some others have unexpectedly generated inconclusive results (Sigalas, 2010; Wilson, 2011; Llurda et al., 2016). The positions of Sigalas (2010) and Wilson (2011) are particularly critical here. Sigala argues that the programme does not strengthen participants' European identity; on the contrary, it can have an adverse effect on it. For instance, he claims that an Erasmus sojourn in England undermined a student's European identity. According to Wilson (2011), this is because Erasmus students appear in research as more proEuropean, so they already had a favorable view of Europe when they decided to 
participate in the programme, otherwise, during their time abroad, one would have to see a strengthening of their European stance. In line with Sigala's and Wilson's, another recent study uncovered that Erasmus students' sense of Europeanness is not increased as a result of participation. Llurda and his colleagues (2016) present a different aspect, claiming that students do not see themselves as distinctively Europeans but rather Westerners, thus, the Erasmus programme promotes not a specific European identity, but rather a more general Western identity.

The quality of personal contact during the Erasmus period with other Europeans is also considered to be an important decision point for the outcome. Ieracitano (2014) offers that social contact can be counterproductive for European identity because interaction with other foreigners is often superficial and it is more possible that students develop deeper relationships and quality dialogue with people from their own nation. Deucth (1966) argues that superficial contact between students is unlikely to produce any positive results instead of meaningful communication. But interpersonal contact cannot be the only reason for influence during the Erasmus programme, as staying abroad involves many activities that can shape students' views and influence their attitudes in a positive or negative way. According to Fernandez (2005), the concept of mobility should be understood as a social practice based on how the students structure their sense of belonging: according to differences with others, through conflict, negotiations. Cultural diversity is the central element of the European Union, therefore, it needs to be understood whether and to what extent students who took part in an Erasmus sojourn can constitute a belonging for European integration.

In this context, empirical data on the impact of cross border student mobility with a broad perspective is either limited, confusing, or lacks strong methodology. For instance, most of the research cited above rationalised the data on homogenous groups based on origin. Sigalas (2010) directed attention particularly towards British students while Van Mol (2013) and Wilson (2011) aimed at three or four nationalities. In addition, most of the empirical analyses on attitudes towards European integration rely on only the results of Eurobarometer surveys (Bruter, 2005; Citrin \& Sides, 2004; Fligstein, 2008). However, Sigala (2010) claims that using the results of a Eurobarometer survey as an explanatory method does not provide sufficient proof that the Erasmus experience and cross-border mobility foster a European identity. In any case, Wilson (2011) highlights that it is not easy to measure the impact and efficiency of the Erasmus programme because over the years the aims the EU hopes to accomplish changes repeatedly as a result of the political structure of the continent. This argument has been verified lately by developments that tremble the unification of Europe such as Brexit, refugee crisis, or the acceleration of nationalism in European communities.

Based on the theoretical framework developed here, the paper used an exclusively qualitative approach, different from the majority of earlier studies, believing that qualitative evidence tells us more about the content and development of Euro- 
pean identity. Besides, the paper included three different dimensions that challenges previous studies and enables the paper to overcome possible limitations. By doing this, the paper explores the impact of the Erasmus experience and role on identity formation, investigates the effect of national identity over European identity and finally, reveals the impact of cultural differences lived through it. Everything emerges from students' experience from their level of affection or disaffection towards community-based socialising on the research questions below:

$R Q 1$ : Does socialising with other students or locals during the exchange programme promote European identity?

RQ2: What is the role of the national identity of students on the European identification process?

RQ3: Do cultural differences that students have or come across during the foreign stay have any effect on the construction of European identity?

\section{METHODOLOGY AND DATA}

Unlike the majority of existing research (large-scale surveys) on European identity, the study relies on in-depth, semi-structured interviews. Primarily the participants of the study are 26 Erasmus exchange students from 11 European countries. Correspondingly, 20 of the interviewees were participants at the Universitat Pompeu Fabra in Barcelona, Spain and 6 of them were outgoing Catalan Erasmus students from the same university. The number of interviews was not predetermined but 24 participants for Triandafyllidou (2008), 26 participants for Grundy and Jameson (2007), 20 participants for Milner and Sinclair (2005) researched on identity with the interviewing method, thus setting a precedent for researchers. Also, Fernandez (2005) conducted 31 in-depth interviews with exchange students to investigate the citizenship perspective of the Erasmus programme and claimed that population and profile of the students was fairly similar to that used by other researchers.

The research separated the samplings of the study according to two scales. The first of these is Erasmus students attending the University of Pompeu Fabra in Barcelona between the years 2013-2015, as the group of people were easy to contact and convenient to reach, since the researcher was affiliated with the institution. The other scale was Catalan students from the University of Pompeu Fabra participating in the programme in various European countries between the years 2014-2015. The separation between incoming and outgoing students has been designed on purpose as it is presumed that Catalan representation offers a better answer to the question of national identity-European identity relations. Catalonia, as a part of Spain, represents a community with high national feelings, particularly among its youth. A recent study has revealed that young people aged 24 and younger were more pro-independence (68\%) than the average population (53\%) (Intergenerational Foundation, 2017). 
The research described in this study is based on the qualitative paradigm. Firstly, the purpose of applying qualitative methodology is to explore the reasons and the results of the particular situation. This attempt allowed an opportunity to gain multiple perspectives of the participants. Additionally, a qualitative approach helps to understand the European identity concept with a series of references that normally are difficult to grasp by applying quantitative methods. Besides, this research benefitted from the results of some specific Eurobarometer surveys regarding the main vocabulary of the research questions such as national identity, belonging, or youth and education programmes as complementary sources, which allowed this study to see the compatibility of obtained data. As mentioned, scholars conducted their studies by taking advantage of EB surveys (Irina, 2012; Antonsich, 2010), specifically on the concept of European integration (Bruter, 2005; Citrin \& Sides, 2004; Fligstein, 2008). However, as discussed before, data comes from the European Commission's public opinion survey, namely Eurobarometer, deliver quantitative knowledge about the idea of European identity, but it has not been very successful to reveal more in-depth knowledge of what it might mean or not mean to feel European. Therefore, the study here focused more on the qualitative method approach and utilized Eurobarometer surveys to complement existing qualitative research.

The study obtained the main data from semi-structured interviews. This type of interview provided the research with greater knowledge and understanding of what students' perceptions are, how images and ideas about Europe and Europeans are interpreted, and how people connect them with a sense of identity. In this context, the researcher examined both the data from semi-structured interviews and results of Eurobarometer surveys, and applied qualitative content analysis for the study as an aspect of collected data to comply with it. The interviews focused on incoming and outgoing European students aged between 20 and 26, lasting between 18 and 42 minutes, were recorded and carefully transcribed and they were all conducted in Barcelona, Spain.

The results of this paper have been deducted by employing qualitative content analysis. Firstly, the transcripts of the data were read and copied, brief notes were made when interesting and relevant information was found. Secondly, notes were gone through and different types of information were revealed. Thirdly, through the list, each item was categorised (coded) and sub-categorised. In categorisation, the study identified whether or not the categories can be linked in any way and listed them as a major or sub-category (Table 1).

\section{FINDINGS}

It is a fact that the social circles Europeans move around in are becoming more diverse due to integration, travel, or mobility purposes, and it is expected that Europe's 
Table 1. Content analysis categorisation

\begin{tabular}{|l|l|}
\hline $\begin{array}{l}\text { CATEGORY } \\
\text { A: } \\
\text { Sub-categories }\end{array}$ & $\begin{array}{l}\text { ERASMUS PERSPECTIVE } \\
\text { Context of participation } \\
\text { Context of expectation and impression } \\
\text { Context of education }\end{array}$ \\
\hline $\begin{array}{l}\text { CATEGORY } \\
\text { B: } \\
\text { Sub-categories: }\end{array}$ & $\begin{array}{l}\text { EUROPEAN IDENTITY } \\
\text { Context of European Union } \\
\text { Context of we feeling, togetherness } \\
\text { Context of European identity }\end{array}$ \\
\hline $\begin{array}{l}\text { CATEGORY } \\
\text { Sub-categories: }\end{array}$ & $\begin{array}{l}\text { NATIONALISM } \\
\text { Context of identity relations (National and Euro- } \\
\text { pean) } \\
\text { Context of European nationalism } \\
\text { Context of Catalan identity }\end{array}$ \\
\hline $\begin{array}{l}\text { CATEGORY } \\
\text { D: }\end{array}$ & $\begin{array}{l}\text { CULTURAL DIFFERENCES } \\
\text { Context of cultural differences } \\
\text { Context of stereotypes and prejudices } \\
\text { Context of transformation }\end{array}$ \\
\hline
\end{tabular}

Source: Author.

cultural, ethnic, and religious diversity will increase in the decades to come. Hence, participation of students in mobility experiences in different countries will help them to deal with diversity and the gains thus derived will assist students to envisage the social structures better. For instance, one of the long-term qualitative studies conducted by the European Commission, 'Erasmus Impact Study' (2014), was carried out in order to understand the underlying tendencies, facts, and perceptions about the impact of Erasmus mobility on personal development. The findings revealed that more than $90 \%$ of the students wish to go abroad to live, to improve their language skills, to form new relationships, and to develop skills such as adaptability. The data of this study also presents that experience, language, and cultural adaptability are the main concepts, which the students anticipate to have as a result of the Erasmus programme.

I always wanted to go somewhere else. I live with my parents and I wanted to live and experience myself and I wanted to go somewhere around Europe and I chose to go to London because of the city and language (21, female, Catalonia).

In my first month, Catalan language was a barrier to communicate, because, you know, speaking Catalan is kind of an obligation here, then I took Catalan classes and now I am used to speaking, at least trying to speak. I even have Catalan friends (22, female, England).

According to Chomsky (2000) language has an impact on every part of human lives but Mann (1992) claims that only when you combine education and language it become a decisive element in the development of identity, consciousness, and 
awareness. So, in this perspective, investigating the case of Erasmus students in terms of language and integration is intriguing, because even if the students share a set of values, history, or geography, sharing a common language to socialise and to adapt to the host country revealed the signs of European identification. According to Eurobarometer surveys, having foreign language skills may be the cause or result of feeling connected to another country $(346,2011$, p. 40). Fligstein (2008) also claims that people with higher education and knowledge of foreign languages are more likely to have a European identity in order to argue that cross-border mobility leads to European self-identification.

Having said that, the majority of the interviews revealed that language is one of the biggest barriers to socialising with the local community and with local students. As mentioned earlier, when the interaction with other foreigners is superficial, social contact can be counterproductive (Ieracitano, 2014). Our data contests that both incoming and outgoing students have limited social contact with the local community, but students socialised with others as a result of the Erasmus experience. This is also revealed by the study of Sigala (2010). His results showed, despite the fact that studying abroad led to increased socialising with other Europeans, contact with students of the host country remained limited. Another empirical study conducted by Mitchell (2012) also indicated that Erasmus students primarily socialised with other nationalities while abroad for their sojourn. Our data differs from other studies and argues that social interaction contributes to a European identity, but that occurs in a particular contact with other international students, which fosters most effectively rather than contact with the host community.

I think the most important barrier is the language. There are so many people who can't speak English in this community so I communicate with only Erasmus students (23, female, Germany).

In order to investigate if the Erasmus programme helps students to develop a European identity, primarily it needs to be understood the level of knowledge of the students on the concepts of Europe, the European Union, and Erasmus programme. For this reason, students were asked firstly to talk about these concepts, with followup questions such as if the students had any idea on the purpose of the programme. Armingeon writes that support for European integration will increase as more citizens become aware of it; however, it is unlikely to happen "behind the backs" of citizens. (2004, p. 241). In this perspective, all of the students only introduced the thoughts on becoming more European as a result of the Erasmus programme, when they were asked to think about Erasmus based on their experiences. In this sense, our data reveals that being with other Europeans thanks to the Erasmus programme helps students to realize a positive change in their European identity only when they become more aware of it. This result also presents the beneficial side of applying qualitative methodology for the research, as it allowed the paper to delve into the subject of identification. 
Studying in the other universities or living in the other cities make you more understanding and Erasmus makes it easier to integrate to other countries. I think most important thing about Erasmus is to get to know other Europeans (20, female, Italy).

Erasmus basically changes. It has a duty to combine Europe better and get to know other cultures closer and you get a better insight of other cultures, so it is an idea of integration and togetherness (24, male, Germany).

One of the research questions of the study is if socialising with other Europeans makes European identity stronger and enhances the role of national identity. As mentioned, Sigala's study (2010) on cross border mobility found out that the Erasmus student experience abroad and direct interpersonal contact with other nations promote a European identity. Another survey study on the same topic conducted by Mitchell also revealed that $73 \%$ of the students reported that studying in another country made them feel more European. The Erasmus impact study (2014) also revealed that more than $83 \%$ of the students felt more European after their stay abroad. All these studies, together with this one are an indication of an important attitudinal change. However, this paper also discovered that the Erasmus experience not only promotes European identity but also promotes national identity without being an obstacle to developing a European identity.

I firstly feel Catalan but at Erasmus I met many people outside of Europe. Maybe I can say when I met people from Europe, I feel we are the same but people from like America or other places I feel some distance. I feel European but I feel more Catalan, not even Spanish (21, female, Catalonia). Actually, I was not so aware of my German culture or identity before I came here, I realised how German I am and it's not a bad thing (24, male, Germany).

Bruter argues that the concept of Europe differs hugely according to what most respondents mean when they say that they feel European and to understand whether they identify primarily with the European Union as a relevant institutional context defining them as citizens, or to Europe as a cultural community or civilisation to which they identify socially (Bruter, 2005, p. 104). According to Bruter's suggestion, there are many different ideas about Europe that students might have in mind when answering the questions. It should be considered that the answers are also shaped by the public discourse especially generated by European officials. Furthermore, it is important how the EU presents itself and how it is displayed in the media. Many debates on immigrants, European values or on the complex relationship with Islam has made a national version of European identity more visible. This is a way of positioning the 'other' and 'us' and this kind of perspective proves as well how people create their existence by creating their contrast. As mentioned earlier, Llurda (2016) argued a different aspect, claiming that students do not see themselves as distinctively Europeans but rather Westerners, thus the Erasmus programme promotes not a specific European identity but rather a more general Western identity. Even if this argument has been verified with some answers, students also make distinctions between themselves and people from other parts of the world. 
Here European people, we were closer between each other than other nationalities. We have our own conception of the life. It is a really good thing because we are closer with our institutions and our values (22, female, France).

When Catalan students talked about being European compared to other nationalities, all of them introduced their national identity even if it was not the initial question. Castells (2009) explains that Catalan identity comes in the perspective primarily because of the efforts of Spanish centralism to eradicate Catalan identity. But according to the Eurobarometer survey conducted in 2014, this situation is not unique to Catalans. Surveys revealed that most people identified with their nationality before feeling European. However, it is claimed that young people would consider themselves more European in the future if they studied and travel abroad (Aggregate Report, 2014, p. 5). But in our case, a Catalan national identity appears powerful when the students felt the connection between language and belonging. Scholar Joan Pujolar explains the power of the language for Catalan people as he calls it 'cultural catalanisation' (Pujolar, 2008, p. 2). According to him, language is the expression of a collective identity, which connects them with certain origins and plays the main role in becoming a nation.

Our data on Catalan students going abroad found that Catalan national identity becomes stronger when students experienced the exchange programme not only because of speaking their own language but also the social interaction with other students. Social interaction exposes new traditions or oppositions and individuals may begin to protect given identities or to form new ones. This is also about the need for belonging to a group. The sense of belonging to a national group is acquired and maintained in social interaction through language, and this emphasizes that language is not just a symbol of national identity but also embodies it. However, European identity is a dynamic concept so it contains not only to communicate European history or priorities in our lives but also establish a dialogue that will allow the collective construction of the notion and encourage otherness and coexist with our own identity (Gomez, 2003, p. 15).

In my Erasmus, for the first time I felt European when I sat down with my American friends. But I feel Catalan and what makes me Catalan is the language. So if you ask me if Erasmus made my European identity strong, yes, but I guess it made my Catalan identity stronger (20, male, Catalonia).

In recent decades, the most extensive question in identity studies concerns if national and European identities coexist or conflict. According to Udrea's study (2012) on Romanian exchange students, the rising number of Europeans claimed to have both a European identity and national identity. The findings of EB surveys on nationalism also verify the data we have. The surveys showed that respondents see themselves as a national of their own country and a European (2012, p. 56). In terms of the relationship between national identity and European identity, the an- 
swers presented that one identity is not against the other, but these identities help to reveal the other, and they can exist together.

I think Erasmus makes people to realise their national identity. Of course it helps people to know about other cultures and makes them more open-minded but when you are with people from different countries you realise your national identity (21, female, Italy).

One of the research questions of the study is to find out how cultural differences affect the Erasmus experiences regarding the European identification process. Contact between individuals from different ethnic, racial, and national backgrounds has long been seen as an encouraging method to reduce prejudice and foster trust (Pettigrew \& Tropp, 2006). Mobility programmes such as Erasmus appear to create situations in which students from diverse backgrounds meet under favorable conditions. Strongar et al., (1996) finds that study abroad changes stereotypes and improves the attitude towards the host country. According to his study, German students who spent a period of time in the United States developed more positive attitudes towards U.S. citizens because exchange students adapted the host society into their self-concept. Here, it should be mentioned that opinions on stereotypes and prejudices differ quite importantly among EU Member States, as a result of national specifics such as recent political developments, cultural and historical considerations, etc.

Some things are not that important even if they are different. When you understand that you are different then you can have built a relation by taking these differences into account. You can always find something in common and Erasmus makes it easier (20, male, Catalonia).

Differences between people are likely to emerge in response to many factors, such as different social roles, group conflicts differences in power justifications of the status quo, and a need for social identity. Thus, stereotyping may occur in various contexts in order to serve particular functions born from those contexts (Fiske, 1993). The interviews proved that cultural differences among Erasmus students reduced after a period of time. All the students somehow realized the differences between them but socialising with other students helped them to eliminate cultural differences.

I had lots of stereotypes that I didn't know before I came here but they disappeared, because Erasmus does that, because I understood here where stereotypes come from. Because I understand now sometimes you think that's a stereotype but maybe just how other culture is (21, female, The Netherlands).

In the last part of the interviews, our research focused on the changes that might happen to students after the experience. Previous research on mobility discovered that the exchange experience presents various opportunities for substantial personal change. For example, research by Shaftel (2007) introduced that there has 
been a significant improvement in basic characteristics such as open-mindedness, appreciation of diversity, and intercultural adaptability. Zimmermann and Neyer (2013) emphasize that study-abroad experiences have a profound effect on personality characteristics - in particular openness, agreeableness, and neuroticism. This research also discovered how Erasmus helped them to become a better person in many ways and how the changes have taken place in their characters.

\footnotetext{
I feel more independent, stronger, and more confident now, and Erasmus helped me a lot to know many people, such as from Estonia or other countries. And it is true actually; Erasmus helps to get over barriers. You realise for example, Germans are nice and funny, not like what they thought about them. It made me not so stereotypical (20, female, England).
}

One of the analytic reports published as a Eurobarometer survey demonstrated that $57 \%$ of respondents improved their foreign language skills and the second most important benefit of their mobility period was awareness of another culture. Moreover, after the experience, the respondents listed that they have better interpersonal skills. There is no better way to enhance young people's skills and employability than by studying abroad. By the same degree, by uniting young Europeans in common values across national borders, it can foster understanding and solidarity. As Murphy-Lejeune explained, "mobility is a sub-component of human capital, enabling individuals to enhance their skills because of the richness of the international experience gained by living abroad" (2002, p. 51). No other EU programme has been as effective as Erasmus in achieving these goals.

\section{DISCUSSION AND CONCLUSIONS}

Firstly, much evidence suggests that the Erasmus experience promotes European identity as a result of the interaction between students, but students mainly introduced better results when they had a chance to think about the aim of the programme. In addition, as many types of research revealed, interaction with the host country is limited both for incoming and outgoing Catalan students. It is crucial that the places where the students interacted showed parallelism with the other exchange students. This proves that Erasmus helps to create an intercultural environment between students to be connected with each other, but students do not have enough contact with the people of the host country. Moreover, because of the language barrier, high-quality communication takes place mostly between students of the same nationality. It might be argued that the lack of communication with the host country affects the strength of the programme on the level of identity construction, but the data clearly showed that even limited interaction plays an important role.

Secondly, the data indicates that socialising with other Europeans not only promotes European identity but also national identity. A majority of the students claimed that their identity strengthened as a result of observing differences with 
other cultures and all Catalan students felt more Catalan when they socialised with different nationals of the programme. The data revealed that participants do not see European identity as a threat to national identity. Conversely, especially Catalan students were eager to emphasize that they belong to Europe and they are Europeans. However, in some cases, the feeling of national identity is stronger than the feeling of a European identity, and this will likely continue in the foreseeable future. More importantly, the data confirms that European identity has not existed beyond or outside national identities, since national identities contain the elements of a European identity to varying degrees.

Finally, the data suggests that the Erasmus programme has affected perceptions and feelings of the participants and contributed to having collective identities for the people of member states, but in different degrees among communities and countries. Education policies of the EU have, at least to some extent, affected and changed people's perception of 'who they are' and 'what political communities they belong to'. In this way, European self-understanding has been affected by the education programmes. Even if students had problems adapting and to satisfying their expectations, this did not create a problem in promoting European identity. Students were aware of the cultural differences among countries and they specifically mentioned they were not affected by these differences. The data also found that stereotypes and prejudices are not obstacles to European identity and actually, the programme helps to eliminate cultural differences, which eventually leads to the promotion of Europeanness. Interestingly enough, it must be stated that the level of effectiveness of the Erasmus exchange programme depends on the knowledge of the participants. For instance, in this study, the majority of the exchange students were not aware of the real purpose of the Erasmus programme, which means they were participating in the programme without realizing its underlying objectives.

This paper contributed to the emerging literature on the growing trends of the European education programme's impact on the youth identification process by revealing that social contact between students promotes European identity, even if it is not at a high-quality level. Also, the development of European identity appears as a result of Erasmus when students are more aware of the interaction and experiences with other nationalities. Different from other studies, this paper also reveals that the Erasmus experience promotes national identity when students participate in intercultural environments, which make them realize their own identity. There has been much criticism of the Erasmus programme, implying that it has lost its function but many studies, including this one, present that Erasmus still plays a major role in the development of European identity by bringing students together and eliminating cultural differences, even if national feelings always come to the fore. Moreover, the programme increases an attachment to Europe and its institutions by giving an opportunity to students. 


\section{ACKNOWLEDGEMENTS}

This paper is a part of a broader research project entitled "European Identity on the Perspective of Incoming and Outgoing Students: A Study of Stereotypes and Prejudices as Cultural Differences".

\section{REFERENCES}

Allport, G. W. (1954). The Nature of Prejudice. Cambridge, MA: Addison-Wesley.

Antonsich, M. (2010). Exploring the correspondence between regional forms of governance and regional identity. European Urban and Regional Studies, 17(3), 261-276.

Armingeon, K. (2004). From the Europe of nations to the European nation: Introduction. In H. P. Kriesi, K. Armingeon, H. Siegrist, A. Wimmer (Eds.), Nation and National Identity: The European Experience in Perspective (pp. 235-241). Zurich: Purdue University Press.

Boneu, M. S. (2003). What do we mean when we say Europe? In M. I. Gómez-Chacón (Ed.), Individual, Group and Society (pp. 37-47). Bilbao: Humanitarian Net.

Bruter, M. (2005). Citizens of Europe? Basingstoke: Palgrave Macmillan, UK.

Ceka, B., \& Sojka, A. (2016). Loving it but not feeling it yet? The state of European identity after the Eastern enlargement. European Union Politics, 17(3), 482-503.

Castells, M. (2009). The Power of Identity. Oxford: Wiley-Blackwell.

Chomsky, N. (2000). New Horizons in the Study of Language and Mind. Cambridge: Cambridge University Press.

Citrin, J., \& Sides, J. (2004). More than nationals: How identity choice matters in the new Europe. In R. K. Herman, T. Risse \& M. B. Brewer (Eds.), Transnational Identities: Becoming European in the EU (pp. 161-185). Oxford Rowman \& Littlefield Publishers.

Decker, F. (2002). Governance beyond the nation-state. Reflections on the democratic deficit of the European Union. Journal of European Public Policy, 9(2), 256-272.

Deutsch, K. (1953). Nationalism and Social Communication. Cambridge: MIT Press.

Dwyer, M. (2004). More is better: The impact of study abroad program duration, frontiers. The Interdisciplinary Journal of Study Abroad, 10, 151-163.

European Commission (2014a). Erasmus impact study online. Retrieved July 1, 2015 from http:// ec.europa.eu/education/library/study/2014/erasmusimpact_en.pdf.

European Commission (2014b). Eurobarometer Qualitative Study: The Promise of EU. Retrieved April 22, 2016 from http://ec.europa.eu/commfrontoffice/publicopinion/archives/quali/ql_6437 _en.pdf.

Fernandez, O. (2005). Towards European citizenship through higher education? European Journal of Education, 40(1), 59-68.

Figel, J. (2006). My vision for European student mobility in the next decade. Speech at the UK Erasmus Student Committee Conference, EUROPA Press Releases no. 06/398.

Fligstein, N. (2008). Euro-Clash: The EU, European Identity, and the Future of Europe. Oxford: Oxford University Press.

Fiske, S. T. (1993). Controlling other people: The impact of power on stereotyping. American Psychologist, 48, 621-628.

Gaertner, S., Dovidio, J., Anastasio, P., Bachman, B., \& Rust, M. (1993). The common ingroup identity model: Recategorization and the reduction of intergroup bias. European Review of Social Psychology, 4(1), 1-26.

Gomez-Chacon, M. I. (2003). Individual, Group and Society. Bilbao: Humanitarian Net. 
Grundy, S., \& Jamieson, L. (2007). European identities: From absent-minded citizens to passionate Europeans. Sociology BSA Publication, 41(4), 663-680.

Habermas, J. (2001). Why Europe needs a constitution. New Left Review, 11, 5-26.

Hall, S. (1996). The question of cultural identity. Modernity, 4, 596-632.

Herrmann, R., \& Brewer, M. B. (2004). Identities and institutions: Becoming European in the EU. In R. Herrmann, T. Risse, \& M.B. Brewer (Eds.), Transnational Identities: Becoming European in the EU (pp. 1-22). Oxford: Rowman \& Littlefield.

Hogg, M. (2006). Social identity theory. In P. J. Burke (Ed.), Contemporary Social Psychological Theories (pp. 112-138). USA: Stanford University Press.

Hofstede, G. (1991). Cultures and Organizations. New York: Mc Graw Hill.

Ieracitano, F. (2014). New European citizens? The Erasmus generation between awareness and scepticism. European Journal of Research on Social Studies, 1, 16-21.

Irina, D. (2012). Rediscovering culture: The unexplored dimension of European democratic identity. Journal for Communication and Culture, 22(1), 88-104.

Intergenerational Foundation (2017). Young Nationalism in Catalonia online. Retrieved September 28, 2018, from http://www.if.org.uk/2017/11/01/young-nationalism-catalonia/.

Jensen, I. (1998). The Practice of Intercultural Communication - Reflections for Professionals in Cultural Meetings. University of Roskilde, Denmark. Retrieved January 27, 2020, from www. immi.se/intercultural/nr6/jensen.pdf.

King, R., \& Gelices, E. R. (2003). International student migration and the European year abroad: Effects on European identity and subsequent migration behavior. International Journal of Population Geography, 9(3), 229-252.

Kohli, M. (2000). The battlegrounds of European identity. European Societies, 2(2), 113-137.

Kohn, H. (1955). Nationalism. Princeton: Van Nostrand.

Kostakopoulou, T. (2001). Citizenship, Identity and Immigration in the European Union. Between Past and Future. Manchester: Manchester University Press.

Llurda, E., Balsa, L. G., Barahona, C., \& Rubio, X. M. (2016). Erasmus student mobility and the construction of European citizenship. The Language Learning Journal, 44(3), 323-346.

Mann, M. (1992). The emergence of modern European nationalism. In J. Hall \& I. Jarvie (Eds.), Transition to Modernity (pp. 137-166). Cambridge: Cambridge University Press.

Meyer, T. (2006). European Identity, Seminar of Summer School, University of Graz. Retrieved May 16, 2016, from http://www.unigraz.at/en/bibwww/bibwww_strategicfocus/bibwww_see/bibwww_see_projects/bibwww_soe_seggau/bibwww_soe_seggau_program/bibwww_soe_seggau_meyer_inhalte.html.

Mitchell, K. (2012). Student mobility and European Identity: Erasmus study as a civic experience. Journal of Contemporary European Research, 8(4), 491-518.

Murphy-Lejeune, E. (2002). Student Mobility and Narrative in Europe. London: Routledge.

Oborune, K. (2013). Becoming more European after ERASMUS? The impact of the ERASMUS program on political and cultural identity. Epiphany JOTS, 6(1), 181-202.

Pettigrew, T. F., \& Tropp, L. R. (2006). A meta-analytic test of intergroup contact theory. Interpersonal Relations and Group Processes, 90(5), 751-783.

Petkova, V. S., \& Mihelj, S. (2012). Europe - a default or a dream? European identity formation among Bulgarian and English children. Ethnicities, 13(5), 565-583.

Pujolar, J. (2008). Youth, language and identity. Revista de Sociolingüística. Retrieved May 20, 2016, from http://www.gencat.cat/llengua/noves/noves/hm08hivern/pujolar1_3.htm.

Renan, E. (1996). What is a nation? In S. Woolf (Ed.), Nationalism in Europe, 1815 to the Present (pp. 48-60). London: Routledge.

Risse, T. (2014). No demos? Identities and public spheres in the Euro crisis. Journal of Common Market Studies, 52(6), 1207-1215. 
Shaftel, J., Shaftel, T., \& Ahluwalia, R. (2007). International educational experience and intercultural competence. International Journal of Business \& Economics, 6(1), 25-34.

Sigalas, E. (2010). Cross-border mobility and European identity: The effectiveness of intergroup contact during the ERASMUS year abroad. European Union Politics, 11(2), 241-265.

Smith, A. (1995). Nations and Nationalism in a Global Era. Cambridge: Polity Press.

Smith, C. E., \& Hopkins R. (2004). Mitigating the impact of stereotypes on academic performance: The effects of cultural identity and attributions for success among African American college students. The Western Journal of Black Studies, 28(1), 312-321.

Sinclair, J., \& Milner, D. (2005). On being Jewish: A qualitative study of identity among British Jews in emerging adulthood. Journal of Adolescent Research, 20(1), 91-117.

Stoeckel, F. (2016). Contact and community: The role of social interactions for a political identity. Political Psychology, 37(3), 431-442.

Tajfel, H. (1981). Human Groups and Social Categories: Studies in Social Psychology. Cambridge: Cambridge University Press.

Triandafyllidou, A. (2008). Popular perceptions of Europe and the nation: The case Of Italy. $\mathrm{Na}$ tions and Nationalism, 14(2), 261-282.

Turner, J. C., Hogg M. A., and Oakes P. J. (1987). Rediscovering the Social Group: A Self-Categorization Theory. Oxford: Blackwell.

Udrea, G. (2012). European identity and Erasmus mobility: Insights from Romanian students' experiences. Romanian Journal of Communication and Public Relations, 14(5), 21-32.

Van Mol, C. (2013). Intra-European student mobility and European identity: A successful marriage? Population, Space and Place, 19(2), 209-222.

Van Mol, C. (2018). Becoming Europeans: The relationship between student exchanges in higher education, European citizenship and a sense of European identity. The European Journal of Social Science Research, 31(4), 449-463.

Wilson, I. (2011). What should we expect of 'Erasmus Generations'? Journal of Common Market Studies, 49(5), 1113-1140.

Zimmermann, J., \& Neyer, F. J. (2013). Do we become a different person when hitting the road? Personality and development of sojourners. Journal of Personality and Social Psychology, 105(3), $515-530$. 